\title{
Control of oestrus and fertility in gilts with accessory corpora lutea by prostaglandin analogues, ICI 79,939 and ICI 80,996*
}

\author{
H. D. Guthrie† and C. Polge \\ A.R.C. Unit of Reproductive Physiology and Biochemistry, Animal Research Station, \\ 307 Huntingdon Road, Cambridge CB3 OJQ, U.K.
}

Treatment of cows or mares with prostaglandin (PG) F-2 $\alpha$ as early as Days 4 or 5 of the oestrous cycle causes regression of corpora lutea (CL) and results in oestrus 2-4 days after treatment (Lauderdale, 1972; Rowson, Tervit \& Brand, 1972; Douglas \& Ginther, 1972; Allen \& Rowson, 1973) However, the CL of pigs do not regress in response to PGF-2 $\alpha$ until Days 11-12 of the cycle (Gleeson, 1974; Guthrie \& Polge, 1976). Because the secretory activity of the CL in the pig declines rapidly by Days 14 or 15 of the cycle, the effective period for synchronization of oestrus by PGF- $2 \alpha$ treatment is too short to be of practical use. Exogenous gonadotrophins induce the formation of accessory CL at any stage of the oestrous cycle of the pig (Neill \& Day 1964; Day, Neill, Oxenreider, Waite \& Lasley, 1965; Caldwell, Moor, Wilmut, Polge \& Rowson, 1969) and the CL formed on Days 8, 10 or 16 delayed oestrus for at least 15 days (Caldwell et al., 1969). We therefore investigated the possibility of synchronizing oestrus in gilts by inducing accessory CL to delay oestrus and ovulation and then injecting PGF- $2 \alpha$ analogues to regress the accessory CL at a predetermined time.

\section{Methods}

Mature, crossbred Large White gilts were exposed once daily to a vasectomized boar to check for oestrus. The first day of oestrus was designated as Day 0 of the cycle and the gilts were assigned to one of three experiments after at least one oestrous cycle.

Accessory CL were induced by a single s.c. injection of PMSG (Folligon: Organon); 1000 or 1500 i.u. were given to 22 gilts in Exp. 1 and 1500 i.u. to 29 and 35 gilts in Exps 2 and 3, respectively. After 72 or $96 \mathrm{hr}$ in Exp. 1 and $72 \mathrm{hr}$ in Exps 2 and 3, an i.m. injection of 750 i.u. HCG (Chorulon: Organon) was given. The injections were administered in $3-4 \mathrm{ml} \mathrm{0.9 \% (w/v)} \mathrm{NaCl} \mathrm{solution.} \mathrm{In} \mathrm{Exps}$ 1 and 3 the gonadotrophin treatments were administered at random to cyclic gilts so that accessory CL were formed in different stages of the cycle. In Exp. 2, PMSG was given on Days 1, 3, 7, 11, 13, 15 or 18 of the cycle to 4 gilts on each day except for 5 gilts on Day 15.

The PGF-2 $\alpha$ analogues (Imperical Chemical Industries Ltd) were injected i.m. in 1-2 ml 0.9\% (w/v) $\mathrm{NaCl}$ solution 12 days after the HCG as follows; one injection of $0.5 \mathrm{mg}$ ICI 79,939 (Exp. 1), two injections of $0.5 \mathrm{mg}$ ICI 79,939 $24 \mathrm{hr}$ apart (Exp. 2), and injections of $1.0 \mathrm{mg}$ and $0.5 \mathrm{mg}$ ICI $80,99624 \mathrm{hr}$ apart (Exp. 3). In Exp. 2 an additional injection of 1000 i.u. PMSG was given to 2 gilts in each of the 7 experimental groups, at the time of the second ICI 79,939 injection, to control more precisely the onset of oestrus. These two PGF-2 $\alpha$ analogues have approximately equal luteolytic effects on Day 12 of the oestrous cycle (unpublished observations).

Luteal function was monitored by radioimmunoassay of plasma progesterone concentration by methods similar to those of Henricks, Hill, Dickey \& Lamond (1973). Blood samples were withdrawn from the anterior vena cava into a heparinized syringe and the plasma was stored at $-20^{\circ} \mathrm{C}$ until assayed. The antiserum (465/5), produced to an $11 \alpha$-succinyl progesterone-bovine serum albumin conjugate, was provided by Dr B. J. Furr of ICI Ltd. When $100 \mu$ l antiserum were used at a dilution

\footnotetext{
* Reprint requests to Dr C. Polge.

$\dagger$ Present address: U.S.D.A., A.R.S., Beltsville Agricultural Research Center, Beltsville, Maryland 20705, U.S.A.
} 
of $1: 4000$ about $65 \%$ of $0.01 \mu \mathrm{Ci}\left[1,2,6,7-{ }^{3} \mathrm{H}\right]$ progesterone was bound. The antiserum was highly specific for progesterone: only $17 \alpha$-hydroxyprogesterone, $\Delta^{5}$-pregnenolone and $17 \alpha$-hydroxy- $\Delta^{5}$ pregnenolone had significant cross-reactivities $(1 \cdot 0,3 \cdot 4$ and $1 \cdot 3 \%$ respectively).

In Exp. 3, gilts that exhibited oestrus 4-7 days after the first ICI 80,996 injection were artificially inseminated once on the 2 nd day of oestrus with $100-150 \mathrm{ml}$ fresh, undiluted boar semen. Half of the gilts were subjected to laparotomy 5-7 days after the onset of oestrus to record the number of CL and to recover ova. The ova were flushed from the anterior part of each uterine horn with $40 \mathrm{ml}$ sterile $0.9 \%(\mathrm{w} / \mathrm{v}) \mathrm{NaCl}$ solution. The ova were prepared as whole mounts, fixed in $25 \%$ acetic alcohol, and stained with $1 \%$ lacmoid in $45 \%$ glacial acetic acid for cytological examination by phase-contrast microscopy. The remaining gilts were killed 27-30 days after the onset of oestrus to record thenumber of $\mathrm{CL}$ and embryos.

The results from Exps 1 and 3 were classified according to the stage of the oestrous cycle at which PMSG was given, Days 0-4, 5-9, 10-14 and 15 to the day before oestrus, for statistical comparison of the proportion of gilts exhibiting luteal regression and oestrus after treatment with the PGF- $2 \alpha$ analogue. Plasma progesterone concentrations were evaluated by analysis of variance. Treatment effects were tested at the $5 \%$ level of significance (Steel \& Torrie, 1960).

\section{Results}

Gonadotrophin treatment started on or before Day 14 caused oestrus to be suppressed during the 12-day interval between the HCG and analogue injections. Treatment initiated between Day 15 and the day before the expected oestrus resulted in oestrous cycles of normal length (18-23 days) for 15 of 24 gilts which returned to oestrus 1-5 days after the PMSG injection.

In addition to the induced accessory $\mathrm{CL}$, the spontaneous $\mathrm{CL}$ in many gilts may have remained functional after Day 14 of the treatment oestrous cycle. Ovulation probably occurred between 40 and $42 \mathrm{hr}$ after the HCG injection (Dziuk, Polge \& Rowson, 1964; Hunter, 1967) or about 5 days after the PMSG injection, and the high progesterone concentrations on Days 16 and 18 in $16 / 21$ gilts in Exp. 2 (Table 1) were presumably due to maintenance of the spontaneous CL.

Table 1. Effect of gonadotrophin treatment of gilts on the induction of accessory CL and on luteal function (Exp. 2)

\begin{tabular}{|c|c|c|c|c|c|c|}
\hline \multirow{2}{*}{\multicolumn{2}{|c|}{$\begin{array}{c}\text { Day of } \\
\text { treatment }\end{array}$}} & \multirow{3}{*}{$\begin{array}{c}\text { Condition } \\
\text { of } C L\end{array}$} & \multirow{3}{*}{$\begin{array}{l}\text { No. of } \\
\text { gilts }\end{array}$} & \multirow{2}{*}{\multicolumn{3}{|c|}{$\begin{array}{l}\text { Plasma progesterone (ng/ml, } \\
\text { mean } \pm \text { S.E.M.) } \\
\text { Day of the oestrous cycle }\end{array}$}} \\
\hline & & & & & & \\
\hline PMSG & HCG & & & 14 & 16 & 18 \\
\hline 3 & 6 & Maintained & 4 & $52.4 \pm 15.9$ & $56 \cdot 2 \pm 32 \cdot 3$ & $47 \cdot 1 \pm 28 \cdot 2$ \\
\hline 7 & 10 & Maintained & 4 & $67.5 \pm 8.7$ & $81 \cdot 6 \pm 16.0$ & $77 \cdot 6 \pm 12 \cdot 0$ \\
\hline 11 & 14 & $\begin{array}{c}\text { Maintained } \\
\text { Regressed }\end{array}$ & $\begin{array}{l}3 \\
1\end{array}$ & $\begin{array}{l}61 \cdot 7 \pm 7 \cdot 7 \\
32 \cdot 3\end{array}$ & $\begin{array}{l}46.7 \pm 0.9 \\
10.2\end{array}$ & $\begin{array}{c}72 \cdot 5 \pm 4 \cdot 4 \\
3 \cdot 3\end{array}$ \\
\hline 13 & 16 & $\begin{array}{l}\text { Maintained } \\
\text { Regressed }\end{array}$ & $\begin{array}{l}3 \\
1\end{array}$ & $\begin{array}{l}48 \cdot 8 \pm 11 \cdot 6 \\
23 \cdot 9\end{array}$ & $\begin{array}{l}44.9 \pm 1.9 \\
2.8\end{array}$ & $\begin{array}{c}55 \cdot 1 \\
3.1\end{array}$ \\
\hline 15 & 18 & $\begin{array}{l}\text { Maintained } \\
\text { Regressed }\end{array}$ & $\begin{array}{l}2 \\
3\end{array}$ & $\begin{array}{l}53.9 \pm 9.7 \\
26.5 \pm 11.7\end{array}$ & $\begin{array}{r}52.2 \pm 3.6 \\
8.7 \pm 6.9\end{array}$ & $\begin{array}{r}37.4 \pm 1.6 \\
2.1 \pm 0.4\end{array}$ \\
\hline
\end{tabular}

The effects of the analogue treatment on the number of gilts exhibiting luteal regression and oestrus are shown in Table 2. Luteal regression, based on plasma progesterone concentrations and the occurrence of oestrus, appeared to be complete in 54,83 and $89 \%$ of the gilts in Exps 1, 2 and 3, respectively and the sensitivity of the accessory CL to ICI 79,939 and ICI 80,996 was similar to that of spontaneous CL in gilts treated with ICI 79,939 on Days 11 and 12 of the cycle (Guthrie \& Polge, 1976). 
Table 2. Effect of treatment with PGF-2 $\alpha$ analogues, ICI 79,939 or ICI 80,996 , on luteal function and oestrus in gilts with accessory CL

\begin{tabular}{cccccc}
\hline & & No. of & \multicolumn{4}{c}{ No. of gilts showing: } \\
\cline { 6 - 7 } Exp. & $\begin{array}{c}\text { Analogue } \\
\text { (dose) }\end{array}$ & $\begin{array}{c}\text { gilts } \\
\text { treated }\end{array}$ & $\begin{array}{c}\text { Induced luteal } \\
\text { regression }\end{array}$ & $\begin{array}{c}\text { Oestrus within } \\
4-7 \text { days }\end{array}$ & $\begin{array}{c}\text { Delayed luteal } \\
\text { regression }\end{array}$ \\
\hline 1 & $79,939(0.5 \mathrm{mg})$ & 22 & $13^{*}$ & 11 & 7 \\
2 & $79,939(0.5 \mathrm{mg}+0.5 \mathrm{mg})$ & 29 & 24 & 19 & 5 \\
3 & $80,996(1.0 \mathrm{mg}+0.5 \mathrm{mg})$ & 35 & 31 & 30 & 4 \\
Totals & & 86 & 68 & 60 & 16 \\
\hline
\end{tabular}

* Two gilts had exhibited luteal regression before treatment and were not included.

The failure of 16 gilts to exhibit a positive oestrous response was due to incomplete luteal regression. The progesterone concentrations before the first analogue injection were higher in these gilts than in those in which the CL had regressed completely (Table 3). Eight gilts did not exhibit oestrus until after the 4-7 day interval following the analogue-induced luteal regression. Plasma progesterone concentrations in these gilts were $<1 \mathrm{ng} / \mathrm{ml}$, indicating that ovulation had also been delayed.

Table 3. The luteal response of gilts to treatments with PGF-2 $\alpha$ analogues

\begin{tabular}{|c|c|c|c|c|c|c|}
\hline \multirow[b]{3}{*}{ Exp. } & \multirow{3}{*}{$\begin{array}{l}\text { Analogue } \\
\text { (dose) }\end{array}$} & \multirow{3}{*}{$\begin{array}{l}\text { Condition } \\
\text { of } C L\end{array}$} & \multirow{3}{*}{$\begin{array}{l}\text { No. of } \\
\text { gilts }\end{array}$} & \multicolumn{3}{|c|}{$\begin{array}{c}\text { Plasma progesterone (ng/ml, } \\
\text { mean + S.E.M.) }\end{array}$} \\
\hline & & & & \multirow{2}{*}{$\begin{array}{l}\text { Before } \\
\text { treatment }\end{array}$} & \multicolumn{2}{|c|}{ After treatment } \\
\hline & & & & & $48 \mathrm{hr}$ & $96 \mathrm{hr}$ \\
\hline \multirow[t]{2}{*}{1} & $79,939(0.5 \mathrm{mg})$ & Regressed & $13^{*}$ & $44 \cdot 0 \pm 7 \cdot 2$ & $4 \cdot 6 \pm 1 \cdot 5$ & - \\
\hline & & Maintained & 7 & $49.8 \pm 6.9$ & $33 \cdot 9 \pm 3 \cdot 3$ & - \\
\hline \multirow[t]{2}{*}{2} & $79,939(0.5 \mathrm{mg}+0.5 \mathrm{mg})$ & Regressed & 24 & $58.7 \pm 8.6$ & $3.8 \pm 0.5$ & $2 \cdot 1 \pm 0 \cdot 2$ \\
\hline & & Maintained & 5 & $113 \cdot 1 \pm 33 \cdot 5$ & $57 \cdot 4 \pm 37 \cdot 7$ & $41 \cdot 1 \pm 26 \cdot 3$ \\
\hline \multirow[t]{2}{*}{3} & $80,996(1.0 \mathrm{mg}+0.5 \mathrm{mg})$ & Regressed & 31 & $71 \cdot 2 \pm 7 \cdot 9$ & - & $3.3 \pm 0.2$ \\
\hline & & Maintained & 4 & $165 \cdot 2 \pm 66 \cdot 6$ & - & $65 \cdot 5 \pm 22.9$ \\
\hline
\end{tabular}

* Two gilts had exhibited luteal regression before treatment and were not included.

Administration of 1000 i.u. PMSG at the time of the second ICI 79,939 injection in Exp. 2 significantly increased the proportion of gilts that returned to oestrus: 11 exhibited luteal regression and 10 of these returned to oestrus in 4-5 days compared to only 1 of 8 gilts exhibiting luteal regression and not given additional PMSG.

The conception rate for the 30 inseminated gilts in Exp. 3 was $80 \%$. Thirteen of 15 gilts killed on Days 5-7 of pregnancy were pregnant with a mean \pm S.E.M. number of $12.0 \pm 0.9$ embryos and $13 \cdot 7 \pm 0 \cdot 6$ CL per gilt. By Days 27-30, 11 of 15 gilts were pregnant with $11 \cdot 5 \pm 1 \cdot 0$ embryos and $15 \cdot 2 \pm$ $1.6 \mathrm{CL}$ per gilt. Although these results are preliminary, they are similar to those of experiments using methallibure to synchronize oestrus (Gerrits \& Johnson, 1964; Polge, 1964) and could offer the basis for a new method of oestrous synchronization in gilts.

We thank Imperial Chemical Industries Ltd, for the PGF-2 $\alpha$ analogues, and the Royal College of Veterinary Surgeons Trust Fund for the Meat and Livestock Commission Senior Fellowship in Animal Health to H.D.G. 


\section{References}

Allen, W.R. \& Rowson, L.E.A. (1973) Control of the mare's oestrous cycle by prostaglandins. $J$. Reprod. Fert. 33, 539-543.

Caldwell, C.V., Moor, R.M., Wilmut, I., Polge, C. \& Rowson, L.E.A. (1969) The relation between day of formation and functional lifespan of induced corpora lutea in the pig. $J$. Reprod. Fert. 18, $107 \sim 113$.

Day, B.N., Neill, J.D., OXenreider, S.L., Waite, A.B. \& LASLEY, J.F. (1965) Use of gonadotrophins to synchronize estrous cycles in swine. J. Anim. Sci. 24, 1075-1079.

Douglas, R.H. \& Ginther, O.J. (1972) Effect of prostaglandin $F_{2 \varepsilon}$ on length of diestrus in mares. Prostaglandins 2, 265-268.

Dziuk, P.J., Polge, C. \& Rowson, L.E.A. (1964) Intrauterine migration and mixing of embryos in swine following egg transfer. J. Anim. Sci. 23, 37-42.

GerRits, R.J. \& Johnson, L.A. (1964) The effect of an orally administered non-steroid on estrus, ovulation and fertility in gilts. Proc. 5th Int. Congr. Anim. Reprod. \& A.I., Trento, Vol. III, pp. 455-459.

GleEson, A.R. (1974) Luteal function in the cyclic sow after infusion of prostaglandin $\mathrm{F}_{2 \alpha}$ through a uterine vein. J. Reprod. Fert. 36, 487-488, Abstr.

Guthrie, H.D. \& Polge, C. (1976) Luteal function and oestrus in gilts treated with a synthetic analogue of prostaglandin F-2 $\alpha$ (ICI 79,939) at various times during the oestrous cycle. J. Reprod. Fert. 48, 423425.

HenRicks, D.M., Hill, J.R., Dickey, J.F. \& LAmond, D.R. (1973) Plasma hormone levels in beef cows with induced multiple ovulations. J. Reprod. Fert. 35, 325-333.

HUNTER, R.H.F. (1967) Porcine ovulation after injection of human chorionic gonadotrophin. Vet. Rec. 81, 21-23

LAUDERDALE, J.W. (1972) Effects of PGF P $_{2 x}$ on pregnancy and estrous cycle of cattle. J. Amin. Sci. 35, 246, Abstr.

NeILl, J.D. \& DAY, B.N. (1964) Relationship of developmental stage to regression of the corpus luteum in swine. Endocrinology 74, 355-360.

Polge, C. (1964) Synchronization of oestrus in pigs by oral administration of ICI compound 33838. Proc. Sth Int. Congr. Anim. Reprod. \& A.I., Trento, Vol. II, p. 388.

Rowson, L.E.A., Tervit, R. \& Brand, A. (1972) Synchronization of oestrus in cattle by means of prostaglandin. Proc. 7th Int. Congr. Anim. Reprod. \& A.I., Munich, Vol. II, pp. 865-869.

Steel, R.G.D. \& TorRIE, J.H. (1960) Principles and Procedures of Statistics. McGraw-Hill, New York.

Received 21 May 1976 